\title{
THE CANADIAN POINT SYSTEM AND ITS DISCONTENTS: INTEGRATION OF IMMIGRANTS INTO THE LABOUR MARKET INTO THE $21^{\text {st }}$ CENTURY
}

by

Elsa Lopez, BA, York University, 1998; B.S.W., York University, 2003

A Major Research Paper

presented to Ryerson University

in partial fulfillment of the requirements for the degree of

Master of Arts

in the Program of

Immigration and Settlement Studies

Toronto, Ontario, Canada, 2007

(C) Elsa Lopez 2007 
UMI Number: EC53441

\section{INFORMATION TO USERS}

The quality of this reproduction is dependent upon the quality of the copy submitted. Broken or indistinct print, colored or poor quality illustrations and photographs, print bleed-through, substandard margins, and improper alignment can adversely affect reproduction.

In the unlikely event that the author did not send a complete manuscript and there are missing pages, these will be noted. Also, if unauthorized copyright material had to be removed, a note will indicate the deletion.

\section{UMI}

UMI Microform EC53441

Copyright 2009 by ProQuest LLC

All rights reserved. This microform edition is protected against unauthorized copying under Title 17, United States Code.

ProQuest LLC

789 East Eisenhower Parkway

P.O. Box 1346

Ann Arbor, MI 48106-1346 
I hereby declare that I am the sole author of this major research paper.

I authorize Ryerson University to lend this paper to other institutions or individuals for the purpose of scholarly research.

I further authorize Ryerson University to reproduce this paper by photocopying or by other means, in total or in part, at the request of other institutions or individuals for the purpose of scholarly research. 


\section{Acknowledgements}

I would like to thank Dr. Mustafa Koc for his insightful and valuable comments throughout the development of this paper. Dr. Koc has acted as a mentor and has been a source of support and guidance during this project. I would also like to thank Dr. Myer Siemiatycki for acting as my second reader and for always demonstrating enthusiasm for the subject and encouraging the pursuit of excellence.

I would like to thank my family, especially my husband Michael and my mother Margarita, for their unconditional support. Without them, this project would not have been possible. 


\title{
THE CANADIAN POINT SYSTEM AND ITS DISCONTENTS: INTEGRATION OF IMMIGRANTS INTO THE LABOUR MARKET INTO THE $21^{\text {st }}$ CENTURY
}

CElsa Lopez, 2007

\author{
Master of Arts \\ Immigration and Settlement Studies \\ Ryerson University
}

\begin{abstract}
This paper offers a historical review of the evolution of the point system. It is crucial to understand the past in order to understand immigrants' current economic performance. Canada's immigration policy has evolved over time by adjusting to the economic, social and political needs of each specific period. However, the current immigration policy, in the form of the point system, is not flexible in meeting the needs of the Canadian labour market. The point system currently requires immigrants to have a high level of education and proficiency in English or French. However, research indicates that immigrants are not doing as well as expected financially. This paper will analyze and seek answers to the following research questions: Does the point system reflect the needs of the labour market and is it an effective tool for measuring the needs of the Canadian nation? The theoretical frameworks that will be used are human capital theory and labour market segmentation theory. This paper will be focusing on the relationship between Canadian immigration policy and the needs of the labour market.
\end{abstract}

Key Terms: Canada; Point System; Immigrants; Blue-Collar Workers. 


\section{Table of Contents}

$\begin{array}{ll}\text { Introduction } & 1\end{array}$

Theoretical Frameworks 3

History of Canadian Immigration Policy and the Point System 11

Canadian Immigrants' Economic Performance 28

$\begin{array}{ll}\text { Discussion and Conclusion } & 39\end{array}$

The Canadian Point System from 1967 to the Present - Table 1

Historical Canadian Immigration Policy Events from 1967 to the Present - Table $2 \quad 44$

Canadian Immigration Levels Plan 2007 and Admission Category - Table 346 


\section{Introduction}

The purpose of this paper is to provide an analysis of the Canadian point system from an economic perspective. In addition, this paper attempts to find reasons why immigrants are failing to integrate into the labour market. It is important to study this topic due to the simple fact that the Canadian economy relies heavily on labour to generate funds and because a lack of full participation by these immigrants has a negative effect on the economy. "As Canada's experience shows, the point system does a good job of screening the immigrant pool, and generates a more skilled immigrant flow than a system that does not use any skill filters" (Borjas, 1999, p. 193). Canada has the point system in place to select immigrants based on their human capital and their potential labour market success (Wanner, 2003).

At the beginning of the $21^{\text {st }}$ century, Canada faces a labour shortage crisis, especially in the skilled trades and health care industries (Citizenship and Immigration Canada, 2006). The point system is an aggressive policy designed to attract highly educated and skilled white-collar immigrants who are fluent in English or French. However, research by Bauder (2003) indicates that highly skilled immigrants often end up with "survival jobs" that do not require special skills and are well below their competencies. This is due to a bias towards highly skilled workers in the point system. The point system penalizes blue-collar workers as they are often not qualified to apply under the current immigration policy, primarily because there is no need to be fluent in English or French or have a university degree for many skilled trades. It appears that there is a mismatch between available skills and labour market needs. Consequently, there are many immigrant professionals that are frustrated with a system that is not working 
effectively and many employers have difficulties recruiting workers for blue-collar jobs within the Canadian labour market.

I will offer a quick review of Canadian immigration policy in regards to how it affects the needs of the labour market. I want to explore the conditions that have led to the emergence of the point system. I will examine if the point system reflects the needs of the labour market and if it is an effective tool for measuring the needs of the Canadian nation. This paper will provide an exclusively Canadian perspective on the point system, but some comparisons will be made to the United States in terms of immigration.

This paper will be divided into three sections. The first section will address theoretical frameworks; I will be focusing on human capital theory and labour market segmentation theory. The second section will focus on the history and evolution of the point system and will have two subsections, the first being an overview of the major trends of Canadian immigration policy before the point system and the second covering "the rise of the point system". A special focus on the skilled worker category and the Provincial Nominee Program (PNP) will be provided. The last section will deal with the economic performance of Canadian immigrants. 


\section{Theoretical Frameworks}

I have selected human capital theory and labour market segmentation theory as these frameworks provide an effective foundation for the understanding of immigrants' contributions to the labour market. These two frameworks, although different, complement each other. I will be elaborating on these frameworks and providing evidence of their relevance to immigration.

According to Hiebert (1997), human capital theory assumes that the labour market is an equilibrium seeking mechanism that allocates workers to jobs on the basis of their education, skill, experience and past performance. Employers are portrayed as "rational actors" motivated by economic maximization and, as such, pay attention only to attributes of potential workers that affect their labour performance, such as literacy, numeracy, specific training and experience. It assumes that able workers wishing to improve their position in the labour market need to add to their human capital by learning new skills. In short, the labour market is assumed to be neutral ground that is gender and colour blind and the responsibility falls on the individual to be successful. In relation to immigrants, this theory strongly suggests that if immigrants wish to integrate into the labour market and meet Canadian standards, they must upgrade their skills. One must consider the time and money invested to upgrade skills; it is difficult to work and study at the same time, especially if you have a family to support. Immigrants generally assume that their skills are good enough to meet Canadian standards as they had to pass the point system before entering Canada.

According to Yale-Loehr \& Hoashi-Erhardt (2000), having a point system to determine characteristics of migrants is positive for the economy of a country. Firstly, a 
point system offers "transparency" by allowing the migrant to assess his or her own chances of being able to immigrate. It also gives the potential migrant the opportunity to pursue the immigration process regardless. Having a point system helps us understand how immigrants are selected and shows consistency for all applicants. Secondly, a point system provides mobility for the migrant; it allows the migrant to pursue new job opportunities. Thirdly, a point system improves efficiency in the selection process and minimizes time for the migrant, employer and people who are in charge of the process (p. 8).

In Canada, the current selection system is premised on the capacity of governments to intervene significantly in the efficient management of labour markets and to match the skills of immigrants to Canadian labour market shortages. However, in "a world where technological change is the norm and industries appear and disappear almost overnight, it is no longer possible to micro-manage labour market supply and demand" (Yale-Loehr \& Hoashi-Erhardt, 2000, p. 10). Canada has a "general occupational list" against which potential migrants are assessed, but there was criticism from Canada's Minister of Citizenship and Immigration in 1998 that migrants' flexibility and transferable skills should be considered rather than exclusively focusing on particular occupations (YaleLoehr \& Hoashi-Erhardt, 2000). This list assists potential immigrants in assessing their skills relative to the skills that are in demand in Canada. Citizenship and Immigration Canada (2007) created this list as a tool to aid employers in matching immigrant workers to unfilled positions.

Skilled workers are selected to ensure their success in a fast-changing labour market and immediate economic benefits. The new regulations emphasize the following 
factors: education, English or French language abilities and work experience involving certain skills, rather than specific occupations (CIC, 2007). Citizenship and Immigration Canada (2007) states that the current breakdown of the points for immigrants to apply to Canada are as follows: education, maximum of 25 points; official languages, maximum 24 points; work experience, maximum 21 points; age, maximum 10 points; arranged employment in Canada, maximum 10 points; and adaptability, maximum 10 points. The total maximum of points is 100 and "the minister of Citizenship and Immigration may change the pass mark from time to time to manage the flow of applications more effectively while ensuring economic benefits to Canada" (CIC, 2007, p. 4). The pass mark has been 67 since September 18, 2003.

Citizenship and Immigration Canada (2007) suggests that, in order to be eligible to apply as a skilled worker, a candidate must have at least one continuous year of full-time, paid work experience or the equivalent in part-time continuous employment. The work experience must be in the category of Skill Type 0 or Skill Level A or B in the specified skill categories described in the National Occupational Classification (NOC) list, which has been developed by Human Resources and Social Development Canada (HRSDC). The candidate applying as a skilled worker must have had this experience within the last ten years. The NOC is a classification system for jobs in the Canadian economy and describes duties, skills, talents and work settings for occupations in Canada.

A study by Citizenship and Immigration Canada (1998), revealed that occupational factors are not reliable indicators of future economic success, as "the highest marks for occupational factors frequently do not result in the highest income levels or lowest levels

1. Please refer to Table 1 to see how the point system has changed over time in terms of maximum points given to immigrants. 
of unemployment" (Yale-Loehr \& Hoashi-Erhardt, 2000, p.14). In addition, the study confirms that older workers tend to benefit from high levels of education, experience and arranged employment while the youngest workers have difficulty entering the labour market and maintaining employment (Yale-Loehr \& Hoashi-Erhardt, 2000). Age and education factors relate; when people get older they tend to have a higher level of education and are more socially connected than when they are young. Immigrants who are young must be given an opportunity to enter the labour market as they are the future of the country.

When immigrants migrate to Canada under the skilled worker category, they bring a significant amount of human capital with them from their home country. Human capital refers to the stock of productive skills and technical knowledge embodied in labour (Hiebert, 1997). Skilled worker immigrants bring knowledge, experience and money to the host country. The knowledge that immigrants bring is transportable and shareable and they could transfer it to the labour market. There is a global debate regarding the fair distribution of human capital and it is most pointed with respect to the educated and most talented individuals, who typically migrate from poorer areas to richer places seeking opportunity, making "the rich richer and the poor poorer". When workers migrate, their early care and education, obtained in the source country, generally benefits their new host country. The current Canadian point system awards higher points to immigrants who have higher levels of education and work experience, which is equivalent to the significant accumulation of human capital. There is a "social cost" for immigrants to obtain their 
human capital, which refers to the money that needs to be paid in order to obtain an education, either by an individual or society as a whole.

Labour market segmentation theory proposes that the labour market is a highly stratified arena with some workers receiving more substantial financial rewards than others (Hiebert, 1997). This theory has two crucial elements. First, the labour market can be usefully perceived as being made up several distinct segments with different rules for wage determination and employment policies. Second, access to jobs in at least some sectors at some times is limited in the sense that more people want jobs than there are jobs offered.

The labour market is divided into primary and secondary sectors. The primary sector refers to the "white collar workers" that occupy managerial, professional and executive positions. The secondary sector refers to the "blue collar workers" that occupy manufacturing or service sector jobs. There is a "dual economy" where jobs are split between those that provide workers with the opportunity for upward advancement and those best described as "dead end" jobs.

A growing economy needs all types of skills in order to function. However, immigrants and visible minorities tend to form a significant concentration in secondary sector jobs (Tastsoglou \& Preston, 2006). Although the source country embodies a complex "blend of factors" that are difficult to separate, recent studies point to "racial discrimination within the labour market" (Teelucksingh \& Galabuzi, 2005). This is blamed for higher rates of poverty among racialized groups in Canada. Other factors must also be considered when discussing labour market discrimination, including recognition of credentials, language fluency and experience. 
The Canadian point system is designed to attract highly skilled immigrants. Upon arrival, however, many immigrants are not able to get a job in their field and end up in "dead end" jobs in order to survive. As such, many immigrants have failed to benefit from their educational attainments and have lower returns on education than Canadian born workers (Reitz, 2001). This is a waste of human capital resources and puts Canada in an ethical and moral dilemma; both the source and host countries do not benefit from that human capital. In addition, it suggests that the debate over Canada's ability to attract highly skilled immigrants may be unwarranted (Coulson \& Devoretz, 1993).

Moreover, immigrants whose foreign education and credentials are not recognized in Canada lose access to the occupations they previously held, "an effect known as deskilling" (Bauder, 2003, p. 701). De-skilling specifically affects new arrivals in the skilled workers category and prevents them from reaping the benefits of their skills and of the nominal amount of their education. "Ironically, immigrants in this category are selected by a point system that gives credit to education and credentials that are not recognized in Canada" (Bauder, 2003, p. 708). Although newly arriving immigrants may have the same education and work experience as Canadian educated workers, some of them are excluded from upper labour market segments to which Canadian educated workers have access because of the differential assessment of their credentials. Consequently, there is a division of labour between immigrants and non-immigrants. In short, some foreign born credentials are not the same as credentials for Canadian educated workers and an immigrant's education and work experience are often not transferable. In addition, many upper-segmented occupations in Canada are strictly regulated by professional organizations. Some of the toughest standards are imposed on the medical profession. 
Other occupations that are provincially regulated include law, engineering, nursing, social work and teaching. The lack of a system to assess foreign credentials prior to an immigrant's arrival in Canada makes "it impossible for immigrants to assess the degree of devaluation prior to immigration" (Bauder, 2003, p. 702).

Borjas (1994) uses a labour market segmentation approach; he suggests that there is a "cost-effective" element to immigration. He states that immigrants who have high levels of productivity and who adapt quickly to conditions in the host country's labour market can make significant contributions to the growth of the economy. In contrast, if immigrants lack the skills that employers demand and find it difficult to adapt, immigration may significantly increase the cost associated with income maintenance programs as well as exacerbate the ethnic wage differentials already in existence in the host country (Borjas, 1994, p. 1667). Native born workers should not be concerned that immigrants will be taking away their jobs or that there will be an increase in expenditures on social assistance programs (Hiebert, 2006). Despite the recent economic misfortunes of immigrants, Canada continues to be a country that welcomes immigration. Canada is a nation of immigrants and "the last decade has seen major changes in immigration policy in Canada, one of the leading immigrant-receiving countries and the one with about the highest per capita immigration rate in the world" (Beach, 2006, p. 2).

Critiques of human capital theory and labour market segmentation theory point to limitations of these approaches. One of the criticisms of the concept of human capital is that it tries to explain all differences in terms of wages and salaries (Dickens \& Lang, 1992). The concept of human capital can also be infinitely elastic, including immeasurable variables such as personal character or social network connections. 
The assumption that the labour market is neutral is a highly questionable premise. Time and money is required to upgrade skills; it is difficult to work and study at the same time. Individuals tend to hire workers that will "fit-in" to the corporate culture.

Corporations have the power to determine who will be hired. In addition, the mechanism of social networking plays a key role in getting a job in the Canadian workforce, as career counselors have stated that " $80 \%$ of jobs are unadvertised". It is difficult to have a social network in place if you have arrived recently to Canada. It is not only immigrants, but as well recent Canadian graduates who have to pass through hurdles just to get a job in their field. Corporations behave inconsistently in regards to their hiring processes, as at times people do not get hired because they are considered over qualified, even though it may be their first attempt at employment in their field. Regardless, it appears that immigrants have a tougher time in securing employment than Canadian born workers.

One criticism of labour market segmentation theory is that prestige may be as important as the knowledge gained when determining the value of an education. In other words, credentials are perceived relative to the institution which issued them. Also, a medical degree will have more value in Canada if it came from Canada, the United States or Australia than if the medical degree came from Asia or India. However, some immigrants with medical degrees have been able to successfully match Canadian medical degree standards. Furthermore, this relates to the existence of market imperfections such as non-competing groups and labour market segmentation. In segmented labour markets, the "return on human capital" differs between comparably skilled labour market groups or segments, such as discrimination against ethnic minorities or female employees (Tastsoglou \& Preston, 2006). 


\section{History of Canadian Immigration Policy and the Point System}

The forces that shape Canada's current immigration policy cannot be fully understood without understanding how immigration policy evolved.

Sub_Section A: an Overview of Major Canadian Immigration Policy Trends prior to the Point System

In the past, the key feature of Canadian immigration policy has been its flexibility to adapt to labour market needs, and that flexibility has been demonstrated with the adoption of various acts of parliament. For example, in 1910 with the Immigration Act, Parliament handed over almost unlimited power to the Cabinet to determine who and how many immigrants could immigrate to Canada (Green \& Green, 2004; Green \& Green, 1999). The 1952 Act, which replaced it, moved the power further away from Parliament and to the minister in charge of immigration. The 1992 Act granted the minister and the immigration department increased power; it gave the minister the ability to set limits on the number of people entering in subcategories of the inflow. The immigration department was in a position to exclude potential immigrants who applied and met all official requirements. "The clearest embodiment of the flexibility is found in the fact that all major features of the immigrant regulation system were set in place by Order in Council rather than being debated in Parliament and being made part of the Act" (Green \& Green, 2004, p. 125). This implies that flexibility was useful for Canada in instances where fast actions were needed, such as the Hungarian refugee crisis in 1956 (Kelley \& Trebilcock, 1998).

Before WWI, immigration was a significant tool of long-term economic development, generating inflows of workers to all sectors of the economy (Green \& Green, 1999). In the 1920s it met a combination of short and long-term goals with large 
immigrant inflows being targeted specifically to meeting the demand for labour in the western agricultural sector. Immigration was shut down in the 1930s through to the end of World War II. When it was reopened, the immigration goals were again mixed. Prime Minister King's 1947 statement indicated an emphasis on population growth, but there was an attempt to target unskilled labour for the agriculture, mining and forestry sectors (Green \& Green, 2004; Kelley \& Trebilcock, 1998).

At the end of WWI, the executive decision was made to divide the world into preferred versus non-preferred countries and to create different admission rules for each. Immigrants from Great Britain and the United States were desired the most; Chinese and African immigrants were the least desired source countries (Kelley \& Trebilcock, 1998). This division continued until the early 1960 s when Canada officially moved to a "nondiscriminatory policy". The Canadian government sent a loud and clear message around the world that individuals from any ethnic background could come and contribute to Canada (Green \& Green, 2004; Kelley \& Trebilcock, 1998). In the 1960s, Canadian immigration policy shifted sharply toward being used for shorter term labour market goals, as it was considered valuable to "fill skills gaps in an attempt to steer the industrial structure toward a modern manufacturing base" (Green \& Green, 2004, p. 126). During the expansion of immigration in the last half of the 1980s, the policy switched to long-term demographic goals (CIC, 2006).

A broad regulatory system was established in the 1960 s and continues today. In this system, potential applicants are divided into different classes with different admission standards and processing priorities for each. Immigrants who want to come to Canada generally apply under one of three classes: family, economic or refugee. The family and 
refugee class applicants enter solely based on family ties or refugee status while the independent applicants must go through screening under the point system (Green \& Green, 1999; Kelley \& Trebilcock, 1998). The creation of a separate refugee class was part of a gradual recognition of Canada's international duties toward refugees, which currently form an integral part of Canadian immigration policy legacy. Unfortunately, under the system as it existed until 1993, "those duties had to be met at the expense of assessed immigrants, as the latter group formed a residual in a system with a fixed total inflow and with top processing priority given to the family and refugee classes" (Green \& Green, 2004, p. 126).

The point system reflects long and short-term goals in Canada's immigration policy (Green \& Green, 2004). In the long-term, policy makers aim to generate population growth and wealth and achieve demographic benefits by controlling the size and age composition of the inflow. Other long-term goals include investment, trade flow and benefits from general immigrant characteristics such as flexibility. In contrast, short-term goals involve achieving benefits from meeting immediate shortages in the labour market (Green \& Green, 1999; Kelley \& Trebilcock, 1998). The setting of Canadian immigration policy has often resulted in a basic tension between using immigration as a tool for promoting long-term growth and, at the same time, using it as a tool for short-term labour market policy. This tension can also be seen as a trade-off between quantity and quality of the immigration inflow. However, these two goals are not always in conflict and they can overlap during certain time periods (Green \& Green, 1999). Canada's immigration policies reflect a "cost-effective approach", directed towards minimizing the costs of immigration (Green \& Green, 1999; Borjas, 1994). This tendency can be typical in many countries where the host country hopes that immigration will not require a significant 
investment in terms of social-educational programs for the newcomers (Borjas, 1994).

A key feature of Canadian immigration policy has been a concern that immigration inflows not exceed the "absorptive capacity" of the economy (CIC, 2006; Green \& Green, 2004; Kelley \& Trebilcock, 1998). The concept of "absorptive capacity" refers to the ability of the economy to provide employment for new immigrants at the "prevailing nominal wage" (Green \& Green, 2004; Green \& Green, 1999). In periods of rising unemployment, the "absorptive capacity" for new immigrants' declines and the government takes steps to limit the number of arrivals. This policy is reversed as the domestic labour market tightens. This suggests that large immigrant inflows may remove native born workers in the host economy in the short-term, even if there are offsetting long-term benefits from the inflows (Green \& Green, 1999). Moreover, the concept of "absorptive capacity" is strongly correlated with short-term rather than long-term goals. When governments are using immigration to meet excess demand for certain occupations, then, by definition, the "absorptive capacity" of the economy is being considered. On the other hand, when primarily long-term goals are pursued, then governments are less likely to respond to short-term cost values (Citizenship and Immigration Canada, 2006; Green \& Green, 1999).

Canada introduced the point system in 1967 and it was considered a solution to a political and migratory dilemma, for at that time the nation was facing a massive immigration of unskilled workers (Green \& Green 1999; Kelley \& Trebilcock, 1998). The creation of the point system represented triumph for those who viewed immigration as an

2. Please refer to Table 2 for a summary of historical Canadian immigration policy events from 1967 to the present. 
immediate labour market policy. The changes in point levels assigned to specific professions were distributed to overseas agents on a quarterly basis (Green \& Green, 1995). It appeared that immigration policy could be "micro-managed" and indicated that earning points under the point system was constantly reviewed and changed as information on labour needs became available. In 1967, an applicant needed fifty out of a possible 100 points to be admissible. "Of the total possible points, forty were based on assessment of predicted short-term success in the applicant's intended occupation and destination" (Green \& Green, 1999, p. 432). This implies that short-term needs were being balanced by long-term adjustment factors, such as education, and that the short-term point of view had not won an absolute victory.

The point system provided an objective scale based on the parameters of education, age and language. These parameters would be used to assess an applicant's admission into Canada and was the first major step to limit the "discretionary powers" of immigration officers and to provide them with a set of specific guidelines. "An examination of inflows broken down by occupation indicates that the 1967 changes shifted the inflow away from less skilled categories such as labourers and transportation workers and towards professionals" (Green \& Green, 1995, p. 1038), indicating that potential immigrants had to have human capital value in order to gain access to Canada. CIC (2006) suggests that occupational composition shifts in the points after 1967 indicated that the point system had an effect on the occupational distribution of independent immigrants. However, it is mainly larger shifts in points that cause changes in the inflow. This is a reflection of the fact that since the point system is used to meet so many goals, "its role in fine-tuning any 
one characteristic of the inflow is limited" (Green \& Green, 1995, p.1038). Tools to select immigrants often display such limitations.

The years from 1974 to 1985 were a period when the economy was not stable and immigration inflows were modified accordingly. Immigration fell between 1974 and 1978, rose from 1978 to 1980 and then fell from 1980 to 1986 (Green \& Green, 1999).

Previously, the point system awarded points for age, schooling and language and failed to control an excess supply of immigrants who met such requirements. Furthermore, this failure indicated the difficulty of trying to control both the level and composition of the skilled component of the inflow with points assessed for personal characteristics. In 1974, the Canadian government responded by imposing a ten point penalty assessment if the potential applicant did not have previously arranged employment. Subsequently, the system was successful in decreasing the amount of unskilled workers admitted to Canada (Green \& Green, 1995).

In 1985, the new Conservative government undertook a review of immigration policy, the conclusions from which are evident in a special report to Parliament in June of 1985 and in the Annual Report to Parliament on Future Immigration Levels several months later (CIC, 2006). A key concern in these reports was that the fertility rate in Canadian society had fallen below the replacement level, with the implication that the Canadian population would age further after the turn of the century if immigration was kept at a low level (Citizenship \& Immigration Canada, 2006; Green \& Green, 1999). The report also reflected the need for an increase in the economic component of the inflow. "Attracting these migrants has become increasingly important, as the federal government anticipates 
that immigrants will provide the only source of workforce growth by the year 2011" (YaleLoehr \& Hoashi-Erhardt, 2000, p. 8).

Government policy intended for immigration levels to be increased significantly and restrictions on the economic component to be lifted in an attempt to grow that component along with the overall levels. "Immigration, as an economic policy, would be utilized foremost to bolster population growth and to readjust the age structure of the population so that there would be enough workers to pay for baby boomers' health care and pensions" (Green \& Green, 1999, p. 434), thus implying that Canada was relying heavily on immigration to meet its economic needs. The outcome of these policy decisions was a removal of the requirement for arranged employment for independent applicants in January 1986. That same year the government also added the investor class, applicants within which gained admission by investing specific amounts in Canadian business (Kelley \& Trebilcock, 1998). Business people or entrepreneurs were seen as an expansion of the business component of the inflow. Therefore, they had a special place within the point system. While the business classes have never become more than a small part of the incoming flow, such policy argues that immigration could be used as a tool of capital and as a means of establishing trade links. These two objectives were long-term goals of immigration policy (Green \& Green, 1999; Green \& Green, 1995).

In 1989, the government undertook a demographic review to analyze the consequences of declining birth rates and their implications for immigration policy. The review revealed that immigration policy was not a good instrument for meeting the demographic goals set out in the earlier policy statements. Furthermore, the review indicated that even if immigration would increase tremendously and fifty percent of the 
inflow would be under age fifteen, it would not have a substantial impact on the age structure (Green \& Green, 1999; Borjas, 1994). This was a strong argument against immigration as a solution for an aging population and suggested that maybe immigration policy was also insufficient as a solution for other domestic issues. Consequently, the Canadian government decided to eliminate the requirement that skilled workers must have an offer of employment before entering the country.

In the early 1990s, the government did not focus on demographic goals. It decided to increase the importance of the economic component of the new immigrant entering Canada. A designated occupations list was created which contained professions in short supply in specific provinces of Canada and immigrants who matched these professions were given higher priority for entry into the country. In 1992, the Conservative party introduced a new Immigration Act that was designed to provide greater control over the inflow. The Act provided the department with broad "new regulatory powers", including the power to set limits on components of the inflow and turn away applicants once specific numbers had been reached for a particular category, indicating that the intention was to use immigration for solid economic purposes only. Indeed, the government proposed to use the new Act to "reduce the proportion of the inflow who were in the family class from 52 percent in 1992 to 43 percent by 1995" (Green \& Green, 1999, p. 434).

A new set of regulations were proposed along with the Act in 1995, but did not make use of these powers. The Canadian government had a high level of commitment to "stable inflows of about one percent of the current population and increased the size of the inflow to nearly 250,000 in 1993 in spite of a persistently poor labour market" (Green \& Green, 1999, p. 435). This was the first time in Canadian history that a government had 
responded to high unemployment rates by maintaining and increasing the size of the immigration inflow. It could be argued that the amount of immigrants entering the country is not high enough and a policy to attain inflows of $1 \%$ of the current population is insufficient. Regardless, it is clear that the government believes that decreasing immigration will not resolve domestic unemployment issues.

Current immigration policy is an extension of policies established in the early 1990s. In 1995, the Liberal government designed a document called "Into the $21^{\text {st }}$ Century: A Strategy for Immigration and Citizenship". The document highlighted that Canada was highly committed to keeping immigration at one percent of the population level (Citizenship and Immigration Canada, 2006; Hiebert, 2006; Alboim \& McIsaac, 2007) and refugee management was to be moved into a separate system with separate goals and resources from the rest of inflow. There was specific and clear commitment to achieving approximate equality of the family class and assessed inflows, even if that required falling short of overall target levels (Green \& Green, 1999, p. 435). Furthermore, the document proposed placing family class applicants in a separate class and putting a numerical limit on that class, except for dependent children and spouses. That element of the document reflected a continuation of the economic aspect of the immigrant inflow.

Statements from the "Into the $21^{\text {st }}$ Century" document indicated that the Canadian government no longer perceived fulfilling short term occupational gaps as a worthwhile goal (Alboim \& McIsaac, 2007). The government stated that "filling precise occupational niches is not always effective in meeting long term needs" (Green \& Green, 1999, p. 435; Green \& Green, 1995). In addition, the proposed regulations of 1995 contained a restructuring of the point system with emphasis on "broad occupational classes rather than 
specific categories". The federal government made the commitment to "provide provinces with the opportunity to choose a number of independent immigrants who meet provincial economic objectives" (Green \& Green, 1999, p.435). Therefore, provinces could independently select their immigrants under the Provincial Nominee Program (PNP). Consequently, preferred applicants would be given higher processing priority and extra points. The ability to execute such a task is enforced under the Immigration Refugee Protection Act (IRPA) and provinces do have a limited number of nominees that can enter.

It was highly specific for immigration policy to be used to alter the structure of the Canadian labour market. "The proposed changes (in immigration policy) seek to improve the skills, flexibility and diversity of the Canadian workforce responding to Canada's new, emerging economy" (Ibid in Green \& Green, 1999, p. 435). The government proposed a program be established to point out occupations where there was a shortage of labour and which were closely related to the skills and capacity of a specific immigrant. Thus, rather than making admission conditional on labour shortages in the immigrant's intended profession, the government would admit skilled workers and assist them in the search for jobs, potentially in a different but similar occupation (Citizenship and Immigration Canada, 2006; Green \& Green, 1999).

Current immigration goals are long-term in nature and short-term goals have been abandoned. Concretely, the concept of "absorptive capacity" has become obsolete or abandoned in the government's language and the key evidence for this is the maintenance of large inflows in the face of persistent unemployment (Alboim \& McIsaac, 2007; Reitz, 2005; Green \& Green, 1999). A study reveals that "the numbers of landed immigrants were regressed from 1946 to 1989 on a constant and the detrended annual unemployment 
rate lagged by one year" (Green \& Green, 1999, p. 436). This suggests a correlation between the variables of immigration and the business cycle over a period in which absorptive capacity appeared to be part of policy decisions. The level of the inflow has been reduced in recent years, but to nowhere near the extent one would predict based on earlier responses to "bouts of high unemployment" (Citizenship and Immigration Canada, 2006; Green \& Green, 2004; Green \& Green, 1999). One possible rationale for a large inflow is that the government believes that Canada needs a more flexible workforce. Policy should then be targeted at generating a labour force with the right type of workers, or "flexible workers with broad skills". The shifts in the point system indicate that the government is seeking immigrants with general skills rather than the ones tailored to specific current skill shortages (Green \& Green, 2004).

Many of the new facets of immigration programs are targeted to the goal of ensuring that new immigrants can contribute and integrate into Canada as soon as possible. Current immigrants are not performing as well as expected financially (Alboim, Finnie \& Meng, 2005; Reitz, 2005). The new immigrants need to be highly flexible so there is less chance they will end up collecting welfare or other social support income. There is also the increased demand on language proficiency, either in English or French, in the selection process, as it is argued that immigrants who are fluent in one of the official languages enter the labour market faster. The Canadian government is committed in the present to utilizing immigrants as a source of investment and trade flows (Citizenship and Immigration Canada, 2006; Green \& Green, 1999).

Canada's immigration policy in the $21^{\text {st }}$ century has displaced emphasis on the concept of "absorptive capacity". This concept was introduced and put into action for the 
first time during the recession that followed World War I as a response to demands from labour (Green \& Green, 1999). From that time until 1990, every significant increase in unemployment was matched by substantial cuts in immigration inflow.

\section{Sub-Section B: "Rise of the Point System"}

According to Citizenship and Immigration Canada (2007), the Immigration Refugee Protection Act (IRPA) established three basic categories of permanent resident, which correspond to major program objectives. The three categories relate to reuniting families, contributing to economic development and protecting refugees. The family class comprises foreign nationals sponsored by close relatives or family members in Canada. The economic class comprises people selected for their skills and ability to contribute to Canada's economy, including skilled workers, business persons, live-in caregivers and provincial nominees (CIC, 2007). Refugees and persons in need of protection include persons in Canada whom the Immigration and Refugee Board has accepted as convention refugees or persons in need of protection, and persons in Canada granted protection under pre-removal risk assessment (CIC, 2007, p. 1). Applicants must meet health and security requirements, as well as the selection criteria for the specific classes.

The point system is considered an effective tool for attracting highly skilled immigrants (Beach, 2006; Bauder, 2003), and "determining the national origin mix of the immigrant flow" (Borjas, 1994, p. 1695). Furthermore, the point system is used to determine eligibility for entrance into a country according to the needs of the market place and provides an assessment of potential immigrants based on specific factors for which points are assigned (CIC, 2007; Green \& Green, 1999).

On average, Canada's point system attracts more skillful immigrants compared to 
the United States of America (Borjas, 1994). "The national origin mix of the Canadian immigrant flow, however, is more heavily weighted towards national origin groups that tend to perform well in both the Canadian and U.S. labour market" (Borjas, 1991, p. 23). This is due to the fact that the average skill level of specific "national origin" groups is about the same in Canada and the United States. In other words, immigrants from a specific "national origin" will tend to perform equally the same in the labour market regardless of whether they reside in Canada or the U.S.

The skill deficit for U.S. immigrants arises primarily because the U.S. receives a much larger pool of immigrants from Latin America. A study done by Antecol, CobbClark \& Trejo (2003) found that Census data for 1990-91 indicated higher levels of English fluency, education and income for Australian and Canadian immigrants, relative to the native population, than for U.S. immigrants. A similar study discovered "differences in the national origin mix of immigrants arriving in Canada and the United States since 1965 are mainly responsible for the higher average skills and relative wages of immigrants in Canada" (Borjas, 1993, p. 35).

The assessment of the level of human capital already present in potential migrants is that certain variables such as education, job related experience and labour demands are deemed to be relevant as sources of human capital for the "success" of the newcomers in the host country's economy (Yale-Loehr \& Hoashi \& Erhardt, 2000). In addition, skilled immigrants earn more, pay higher taxes and require fewer social services than less skilled immigrants (Borjas, 1994). However, it has been noted that education, age and occupation, which are quantifiable characteristics emphasized by point systems, account

3. Please refer to Table 1 for a detailed overview of the Canadian point system from 1967 to the present. In addition, please refer to Table 3, for "Immigration Levels Plan 2007 and Admission Categories". 
for "only a third of the variation in earnings among workers in the United States" (YaleLoehr \& Hoashi-Erhardt, 2000; Borjas, 1994). Intangible characteristics, such as the motivation to succeed and personality of person, are not easily measurable and "are the main determinants of what makes some workers successful and others unsuccessful. Furthermore, historical evidence suggests that the difference in earnings between family based migrants and migrants selected for their skills disappears after ten to twenty years" (Yale-Loehr \& Hoashi-Erhardt, 2000, p. 4). This strongly suggests a significant improvement in the economic conditions of the family class over time and eventually they tend to be as successful as the independent and economic classes.

The debate over selecting immigrants based on skills has often divided the labour market into skilled versus unskilled groups, with the assumption that these groups complement each other and that "the demand for Canada's resource output is perfectly elastic" (Green \& Green, 2004, p. 104). In addition, the flexibility of the groups is equivalent to the "elasticity" of the labour market; it is just like a "key in a lock" in the sense that both groups compliment each other.

Applicants for immigration are assessed according to a selection criterion for each designated class. The classes include skilled workers, provincial and territorial nominees, investors, entrepreneurs, self-employed people and live-in caregivers (CIC, 2007). Since 2003, applicants are also subject to a province's selection criteria, as most provinces and territories are becoming highly involved in selecting foreign workers. The Canadian government, under the Immigration and Refugee Protection Regulations, established a provincial nominee program (PNP), allowing provinces and territories that have agreements with $\mathrm{CIC}$ to nominate a certain number of workers (CIC, 2007, p. 1). In that 
program, the provinces select and identify nominees who can meet their specific labour market needs. These nominees must meet federal admissibility requirements such as those related to health and security (CIC, 2007).

The Provincial Nominee Program (PNP), part of the point system, was developed as a series of bilateral agreements with the provinces and territories, with the various provincial programs becoming operational at different times (CIC, 2007; CIC, 2006). In addition, under the Immigration Refugee Protection Act and under the Department of Citizenship and Immigration Act, the Minister of Citizenship and Immigration has the authority to sign agreements with the provinces and territories to facilitate the coordination and implementation of immigration and refugee protection policies and programs. "These agreements highlight immigration as a key area for bilateral collaboration and formalize how the two levels of government work together" (CIC, 2006, p. 10). They also include a variety of annexes which provide for such measures as the provincial delivery of settlement services. The responsibility for nomination lies with the province. Agreements with all the provinces and the Yukon Territory contain provisions for selecting nominees (CIC, 2007).

The Immigration and Refugee Protection Act (IRPA) recognizes Canada's commitment to consulting with the provinces when setting immigration goals and to sharing the benefits of immigration across all regions of Canada (CIC, 2007, p. 1). The Act is applied on the assessment and qualification process of immigrants (Department of Justice Canada, 2007). IRPA provides a clear definition and conditions under which people are subject to enter Canada. Under IRPA, people who are not Canadian citizens may be subject to removal from Canada if they are convicted of an offence in Canada. 
The PNP is meant to provide equal opportunity access of resources to all provinces and territories across Canada and help meet the economic, social and political needs of the provinces. The Canadian provinces and territories signed a contract with the federal government in order to participate in the PNP and they made the commitment to follow certain rules and regulations depending on their agreements.

In British Columbia, an agreement, signed in 1998 and renewed in April 2004, gave the province responsibility and funding for settlement and integration services, a greater role in immigration planning and policy and a provincial nominee program (CIC, 2007).

In 1991, Quebec signed a Canada-Quebec Accord that gave Quebec exclusive responsibility for setting its own annual immigration targets and sole responsibility for selecting immigrants who want to settle in the province, with the exception of members of the family class and refugees whose status are determined by Canada (CIC, 2007: CIC, 2006). Quebec has full responsibility for providing orientation and integration services for new immigrants and those selected by the province receive a document called a "Certificate de selection du Quebec". The federal government ensures that immigrants meet statutory admission requirements such as medical and criminal checks (CIC, 2007, p. 1).

In 1998, Saskatchewan established a provincial nominee program that was renewed and enhanced on May 7, 2005. The agreement included the provision that Saskatchewan would advise Canada regarding its annual immigration level plans for provincial nominees and that the province would exercise its responsibilities in "the development and implementation of programs, policies and legislation, promotion and recruitment of 
immigrants, determination of provincial nominees; and facilitating the settlement and integration of immigrants as set out in this agreement" (CIC, 2007, p.3). The limit on the number of provincial nominations was removed to give Saskatchewan greater flexibility in operating its immigration program.

The Canada-Ontario Immigration Agreement was signed on November 21, 2005. The five-year agreement signals a shared desire to optimize the economic benefits of immigration and ensure that immigration polices and programs respond to Ontario's social and economic development and its labour market priorities. It confirms program objectives and investment priorities "that address a full range of integration needs, including pre-arrival information and orientation, basic settlement services, and language training" (CIC, 2006, p. 11).

The PNP has one main goal, to increase the economic productivity of a specific province or territory. Therefore, the PNP will improve the overall economic performance of Canada. 


\section{Canadian Immigrants' Economic Performance}

Immigrants' tend to have high expectations upon arrival to a host country. They expect to have a better life for themselves and their families. The fact that they have been accepted under the Canadian point system gives them the impression that their skills are considered sufficient to receive employment in their areas of expertise and fuels their high expectations. Instead, they often have a difficult time integrating into Canadian society, primarily due to an inability in finding employment in their field. The ability to find employment is the key factor ensuring effective settlement. Newcomers find "survival jobs" that are not related to their field, which leads to an erosion of their skills. They often work long hours to make ends meet and do not have the time and energy to address unresolved settlement issues. The difficulty in finding meaningful employment is not only frustrating, but erodes their finances, self-esteem, physical, mental, and emotional wellbeing. Their lack of understanding on how the Canadian system works complicates and slows down integration. For professionals, prolonged underemployment or unemployment can lead to de-skilling, seriously affecting their prospects of re-entering their profession. Consequently, it can also result in lower income and downward social mobility (Alboim \& McIsaac, 2007). A report by Statistics Canada found that nearly "one in five of recent immigrants who arrived between 1992 and 2000 were of low income for at least four years during their first five years in Canada, more than double the corresponding rate of around 8\% among Canadian born individuals" (Statistics Canada, 2007, p. 3).

In 1993, the selection system for recruiting immigrants was altered to attract more highly educated immigrants, as well as more economically "skilled" classes. The Canadian government adopted this change as a result of the scarcity of skillful workers in 
Canada at that period of time. Consequently, "the proportion of immigrants entering the country with university degrees rose from $17 \%$ in 1992 to $45 \%$ in 2004 , and the share in the economic skilled immigrant class increased from 29\% to 51\%" (Statistics Canada, 2007 , p. 2). In contrast, before 1963 , immigrants typically did not have a higher level of education and mostly were under-settled.

While the immigrants who are arriving have more education, they also have to compete with an educated Canadian labour force. Immigrants currently arriving, therefore, encounter a much different degree of labour market competition than their previous predecessors. "Their earnings have fallen, therefore, not because of deficiencies in their human capital, but in step with the improvement in the human capital of Canadian born workers" (Hiebert, 2006, p. 42). Canadian universities have increased their university enrollment significantly. Reitz (2001) suggests that competition from the Canadian born is also a contributing factor to labour market outcomes for new immigrants, specifically in a "knowledge economy base" that supports credentials and strongly relies on communication and presentation skills. In addition, another barrier that newcomers encounter in the labour market is that there is emphasis from corporations for potential employees to possess “Canadian experience” (Reitz, 2001).

A study conducted by Statistics Canada (2004) revealed that the proportion of immigrants experiencing low incomes rose between 1980 and 2000 and that this unfortunate pattern was especially relevant for those who had arrived in the five years preceding each census, increasing from 24.6 to $35.8 \%$ (Picot \& Hou in Alboim \& McIsaac, 2007). In the same period, "the low income rate of the Canadian born population actually fell from 17.2 to $14.3 \%$ of the population" (Hiebert, 2006, p. 46). This finding suggests 
that immigrants are competing against each other in the labour market, but not against the Canadian born. Newcomers encounter barriers to effectively competing with the native born, including credential recognition, lack of Canadian labour experience and fluency in English or French (Alboim \& McIsaac, 2007).

A study by Schaafsma \& Sweetman (2001) revealed that an immigrant's age affected outcomes. Those who arrive in their later years, on average, receive low returns for their previously acquired labour market experience and education. The study revealed that visible minority immigrants who landed before their teen years did not have an earning deficit relative to "observationally" equivalent Canadian born; a similar study by Reitz (2005) concluded the same. The study by Reitz found that the return from having the English language as a mother tongue for immigrants born in a host country is elementary similar for immigrants who arrived at a young age. This suggests that "acculturation is an important reason why age at immigration matters for subsequent earnings" (Schaafsma \& Sweetman, 2001, p.1095). Point allocation should be redistributed, since economic integration declines appreciably with age at immigration because older immigrants do not tend to upgrade their skills or return to school. For example, for age, the system allocates the maximum number of points to applicants in the 21-44 year age group. Schaafsma \& Sweetman (2001) support possible revisions that would allocate 10 points to 21-28 year old applicants and then lower this amount by 2 points for each successive four-year age cohort, so that no points are assigned for age to applicants older than 44 years, as opposed to 48 years currently. A study by Wanner (2003) revealed that immigrants selected via the point system have higher earnings upon arrival than those who are not screened, but over time the earnings of the two groups converge (Wanner, 2003, p. 66). For Wanner (2003), 
even entry cohorts containing a large proportion of refugees eventually have earnings similar to the independent and family classes, which presumably have "superior human or social capital".

Critics of the current point system suggest that it should be reformed in order to encourage skilled trades people to apply (Manahan in Jimenez, 2006). They argue that workers in this industry do not require proficiency in the English language, but this is one of the requirements under the current system. Likewise, employers who are in need of construction workers and truck drivers find it very difficult to recruit blue-collar workers. They complain that it is difficult to find people to work in the transportation and construction industry due to the inflexibility of the point system (Argento, 2006).

Likewise, many white-collar immigrants who are in Canada and were able to immigrate through legal venues are not able to find employment in their fields. Moreover, the learning recognition gap for education is so significant that it limits the immigrants' income and employment prospects (The Conference Board of Canada, 2001). For example, International Medical Graduates (IMGs) have a difficult time finding residency spots and are therefore not able to exercise the professions for which they have been trained. It is once again a waste of human capital resources not to have qualified IMGs applying their medical skills where there is a need. In particular, the rural areas of Ontario face a significant shortage of family physicians compared to urban areas. Currently, each of the ten provinces and three territories has its own medical system and professional requirements for licensing, often resulting in conflicting policies, through which IMGs must sort. The fact that the provinces do not have standardized testing for IMGs creates confusion and exacerbates the physician shortage crisis in Canada. In addition, The 
National Physician Survey found that " 60 per cent of family physicians are either limiting the number of new patients they see or are not taking new patients at all" (The Royal College of Physicians and Surgeons of Canada, 2004, p.1).

The underutilization of immigrant skills is a compelling waste of human capital resources. Canada's goal to attract the "best and brightest" is being undermined, thus defeating the purpose of having a point system. The non-recognition of immigrant credentials costs the Canadian economy $\$ 3.42$ billion to $\$ 4.97$ billion annually (Conference Board of Canada, 2001; Reitz, 2001). Moreover, foreign work experience is discounted or devalued by the Canadian labour market, with one year of it being worth only about one-third of a year of Canadian work experience. However, immigrants with a foreign recognition who also obtain a Canadian credential receive a higher return on their total education, implying that a Canadian credential can convert a foreign degree into a more valuable one (Alboim \& McIsaac, 2007; Alboim, Finnie \& Meng, 2005; Reitz, 2001). This implies that immigrants' skills are transferable and, if effective credential recognition mechanisms are established, the Canadian economy will become stronger for the effort. There are multiple factors that impede immigrants from performing at their maximum capacity in the labour market. Most important of these are the lack of systems in place to evaluate immigrants' credentials and the illusion created by the point system that allows immigrants to believe that once they arrive in Canada, they can immediately exercise their profession.

On the other hand, blue-collar workers, who are in demand in the labour market with jobs waiting for them, do not qualify to enter the country under the current point system. The Construction Sector Council report concluded that, between 2006 and 2014, 
"more than 70,000 new workers will be needed in Ontario to meet impending retirements and to meet future demand" (Argento, 2006, p.2). For years, the Canadian Construction Association (CCA) has advocated and implemented measures that will increase the supply of Canadian construction workers. For example, in 2005, the CCA recommended tax credits for companies hiring apprentices and for the apprentices themselves; both measures were contained in the first Conservative budget in May 2006 (Williams, 2006). The CCA asked for changes to the permanent immigration system and the temporary foreign worker system that would place greater emphasis on immigrants with trade skills. At present, the current skilled workers category puts more emphasis on immigrants with credentials or degrees.

The current point system creates a barrier for blue-collar workers as their trade skills are often insufficient to meet the standards of that point system (McConnell, 2006; Yale-Loehr \& Hoashi-Erhardt, 2000). This implies that the point system is not selecting candidates that best qualify to meet the current needs of the Canadian labour market, and is therefore failing immigrants and the economy. Canada faces the challenge of a shortage of skilled workers in the construction industry. In short, there is an increase in construction investment that will soon diminish. According to Gritziotis, executive director of the Construction Sector Council (2006), labour shortage problems are compounded by growing labour demand in British Columbia because of the Olympics, growth in the condo sector, Alberta's oil sands expansion, infrastructure development in Ontario after years of neglect, and the economic expansion of the Atlantic provinces. The Canadian Federation of Independent Business (2005) found that the persistent shortage of qualified, skilled labour challenges small-business owners and threatens their business. A poll in late 2005 
indicated that "one in two small-business owners in Canada (52 \%) named employee shortages as a point of concern" (Bourgeois \& Debus in Alboim \& McIsaac, 2007, p. 5).

Instead of finding a solution to the problem of blue-collar labour shortages, Citizenship and Immigration Canada (CIC) has recently ruled out amnesty for the estimated 200,000 undocumented skilled workers, many of Portuguese and Hispanic descent, who work in the construction industry. CIC has stated that their decision is based on protecting the integrity of the system (CBC, 2006). However, CIC fails to recognize the economic realities and contribution of this sector to the Canadian economy. Moreover, CIC appears not to have considered the money it will spend to recruit, train and bring to Canada new skilled workers from overseas.

A shortage of blue-collar workers is, in part, a domestic problem. There is a societal emphasis on Canadians to pursue a post-secondary education rather than a skilled trade, and "guidance counselors estimate that some 95 per cent of Grade 10 students aspire to university entrance - an unrealistic expectation that is often reinforced by parents" (Economic Council of Canada, 2006, p 12). This implies that young people are not being guided appropriately in regards to job prospects or the demand for jobs in the economy. Also, the performance of the education system in Canada does not assure Canadians of an improved standard of living in the coming years. Students are not being recruited to meet current labour demands and their career choices are often not in alignment with the needs of the labour market. Consequently, individuals have a difficult time finding employment after they graduate from university or college. It appears that there is an emphasis on pursuing higher education, as the path to higher education is associated with a higher social status than can be achieved by pursuing a career in trades. The options for the 
nonacademic student have been neglected and the general disrepute in which vocational programs are held is damaging (Economic Council of Canada, 2006). The current point system does not have a specific section related to vocational programs that would give credit to potential immigrants with vocational skills.

According to the Economic Council of Canada (2006), the shortage of skilled workers in the construction industry is a result of the educational system not working in partnership with employers or corporations. There is no communication between the school system and employers. Canada should not only recruit immigrants to perform bluecollar work, but also Canadians should be recruited to perform low skilled jobs. The point system targets highly skilled immigrants, only to make them perform low skilled jobs (Bauder, 2003). Canada needs an "institutional mechanism to ensure that labour market signals are appropriately and clearly sent or transmitted and correctly read by individuals and the learning institutions" (Economic Council of Canada, 2006, p. 2).

There has been a significant decrease in enrolment pursuing trades for a variety of reasons. Firstly, people entering trades are associated with lower social status. Secondly, the vocational programs have the reputation of being geared towards high-risk nonacademic students or low achievers. Thirdly, the staff members of vocational schools usually do not possess advanced formal qualifications. Finally, post-secondary institutions often do not accept vocational subjects as credits. The image of vocational education and training needs to be improved. Specifically, where secondary school level apprenticeships are offered, they should be coordinated with the regular post secondary apprenticeship system (Economic Council of Canada, 2006). Employers require access to adequately 
trained candidates to alleviate the shortage of labour positions. Therefore, the relationship between employers and the education system needs to be solid and stable.

Canada should also recruit its own population to meets the needs of the labour market as this approach will be logical and cost-effective, especially since it will take time and money for internationally trained professionals to exercise their profession and make a significant contribution to the Canadian economy. In order to alleviate the shortage of workers, employers are able to bring in foreign workers under the Temporary Worker Program (TWP), which is administered by CIC and HRSDC. Corporations have put pressure on Ottawa to increase the capacity and speed the process of the TWP. The TWP could be used inappropriately to circumvent the Skilled Worker Permanent Immigration Program. This means that temporary workers could apply for permanent residence status and, since they are already in Canada, receive higher priority than workers who applied as skilled workers and are still in their home countries (Alboim \& McIsaac, 2007). The TWP was designed to fill short-term needs until permanent employees could be found; it was not intended to be a stepping stone in a permanent immigration process.

According to Alboim \& McIsaac (2007), a temporary worker is not necessarily an effective long-term solution and creates many unforeseen problems. These include the potential exploitation of temporary workers, suppression of wages in certain sectors and the lack of access rights to certain public services by temporary workers and their families. In addition, there will be less incentive for employers to hire or train immigrants that are already in Canada. Another potential difficulty of granting permanent residence to an additional " 25,000 people from within Canada (as estimated in the 2007 Budget [Finance Canada 2007, 218]) is that because they will be accommodated within current immigration 
levels, the 800,000 people currently applying for permanent residence directly from abroad will have to wait even longer to come to Canada" (Alboim \& McIsaac, 2007, p. 6). Importing temporary workers is the equivalent of treating the symptoms of a problem instead of its root causes.

According to Sweetman (2006), given that there is a queue of applicants for the skilled worker category and some are not permitted to immigrate, one cannot help but ask if economic outcomes would be better for families if the criteria were changed to predict the success of both adult partners in the family. This suggests that the point system should award more points under the family category. Since the economic contributions of the family class are higher than the economic class, society as a whole will benefit from such a modification.

Similarly, a Statistics Canada study (2007) suggests that there is a relative difference in the first-year success of family class versus skilled immigrants. It was found that by the 2000s, skilled immigrants were "more likely to enter low income than their family class counterpoints." Improving economic conditions were more important than the immigrant's educational qualifications in assisting upward-mobility from low income categories. In the past, it was thought that family class immigrants with less education were more likely to stay in low income jobs. The study suggests that the family class has a more positive role in the economy than the skilled category. Therefore, closer attention should be given to the family class under the point system. It appears that the family class is successful compared to the skilled category; perhaps there is a strong social network in place that enhances the labour market for the family class. 
To summarize, employers in the construction and transportation industries complain that it is difficult to find workers. A key reason why they find it hard to recruit immigrant workers is the inflexibility of the point system. The current point system focuses on attracting highly educated immigrants and does not have a vocational category under which immigrants can apply. The TWP is insufficient to meet the demands for bluecollar workers. In fact, the program may induce participants to apply for resident status, which was not the original intent. A recent study by Statistics Canada revealed that the family class is doing better financially than the skilled worker category. 


\section{Discussion and Conclusion}

As my historical review explains, the Canadian point system offered a degree of flexibility to policy makers when they responded to changing social, economic and political conditions in the past. Changes were implemented periodically, such as the introduction of the business class in the 1980s and the PNP in 2003, to create new categories in response to changing economic or refugee priorities. This paper argued that the point system, in its current form, is unable to respond to the changing needs of the Canadian labour market.

Since its inception in 1967, the point system was implemented and revised to meet the short and long-term goals of Canada based on the needs of each time period. Canada currently faces a shortage of labour and health care workers, so the point system must be made more flexible to better address these shortages. The PNP has been introduced to meet specific needs of the provinces and territories. The Canadian government has a commitment to significantly increase the number of immigrants each year. However, there is a gap between what immigrants thought their educational qualifications would produce in Canada and what actually happens (Simpson, 2006). Therefore, Canada needs to be more realistic in terms of the admission of immigrants to the country until the problem of foreign credentials recognition is efficiently addressed or better information is provided to prospective immigrants (Doling \& Young, 2004). An effective and fair system is needed to recognize immigrants' credentials and make sure that they meet Canadian standards, especially in language skills (Alboim \& McIsaac, 2007). However, this system must also recognize that certain professions, such as skilled trades, do not require proficiency in English or French. If this is not achievable, Canada should decrease the volume of its 
immigration. In short, a balance between labour market needs and business cycle needs must be established.

The point system in Canada is not unique. Australia has a point system and the United States of America is considering adopting one. In fact, Canada could be used as a model for the U.S. point system, since it attracts skillful immigrants. Before immigrants enter Canada, they should be aware of any educational upgrades that they require in order to exercise their profession and their credentials should be assessed. For example, Australia requires its immigrants to be fluent in English and to be professionally assessed before entering the country (Miller, 1999). Perhaps Canada could do something similar to the Australian system, in order to avoid immigrants' disappointment upon arrival. More points should be awarded to professions that are high in demand and to people who have family members in Canada.

It is my opinion that a subcategory under the point system should be created to accommodate skills that are required from people that do not need to have a postsecondary education or proficiency in English or French. The idea of creating a subcategory will be a sign that the point system is being flexible in meeting the needs of current labour market. History indicates that the point system has been altered before to meet the economic, social and political needs of the time. If this subcategory was adopted and subsequently became a problem, it would be subject to changes as with all aspects of the point system. In fact, a Citizenship and Immigration Report (2006) revealed that the Canadian government is considering creating a category called the "economic immigrant" to address the need for trade skills without the immigrant requiring a university degree or fluency in English or French. 
The fact that many current immigrants are not doing well financially makes Canada appear unprepared to manage the economic, social and political issues that come with a huge influx of immigrants (Economic Council of Canada, 2006). Canada does have settlement services in place to assist newcomers with the Canadian integration process, including agencies like LINC / COSTI that offer English classes and legal or counseling services. The settlement agencies are designed to address settlement issues of newcomers and are limited to addressing labour market integration (Alboim \& McIsaac, 2006). Unfortunately, at present the settlement services are not sufficient to meet the needs of immigrants. These agencies require more funding in order to better assist immigrants with integration; such initiatives will make the Canadian economy stronger. As historical patterns of emigration from Canada have shown, if the government is not financially able or simply unwilling to spend more to assist immigrants, they reduce the level of immigrant retention.

The Canadian government's efforts to assist immigrants are insufficient; more is required to help immigrants to efficiently integrate into the Canadian economy. According to The Conference Board of Canada (2001), "eliminating the learning recognition gap in Canada would give Canadians an additional \$4.1-\$5.9 billion in income annually" (Pg 1). This suggests that investing in immigrants' success will pay dividends. For example, English language classes should be given at different times and throughout the week and weekends to meet the language needs of immigrants. In addition, more funding should be allocated to settlement services to better assist immigrants with integration into the Canadian labour market and society. 
Furthermore, Canada should train its own population to meets the needs of the labour market as this approach will be logical and cost-effective, especially since it takes time and money for internationally trained professionals to exercise their professions and make significant contributions to the Canadian economy. Canada should not rely heavily on other countries to meet its labour needs, needs that could be met by establishing solid and stable relationships between business, government and education systems.

More research is needed to better understand why Canadian society is failing to generate a sufficient pool of labour and why we rely so heavily on imported labour to fulfill our economic needs. Research should also be focused on services available to young immigrants to integrate into the Canadian labour market, as this population is vulnerable and Canada needs young workers to build the future.

The point system must be reformed in order to better allow the entry of blue-collar workers into the Canadian labour market. The current point system does not accurately reflect the needs of the Canadian labour market. The educational system, corporations, settlement services and government should work more closely together to enable Canada to attract and settle the immigrants it needs to build a better future for all Canadians. 
Table 1

The Canadian Point System from 1967 to the Present

(Maximum Points)

\begin{tabular}{|l|c|c|c|c|c|c|c|}
\hline Factor & 1967 & 1974 & 1978 & 1986 & 1993 & 1997 & 2004 \\
\hline Education & 20 & 20 & 12 & 12 & 16 & 16 & 25 \\
\hline Experience & --- & - & 8 & 8 & 8 & 8 & 2 \\
\hline $\begin{array}{l}\text { Specific vocational } \\
\text { preparation or education } \\
\text { training factor }\end{array}$ & 10 & 10 & 15 & 15 & 18 & 18 & -- \\
\hline $\begin{array}{l}\text { Occupational demand or } \\
\text { occupational factor }\end{array}$ & 15 & 15 & 15 & 10 & 10 & 10 & -- \\
\hline Age & 10 & 10 & 10 & 10 & 10 & 10 & 10 \\
\hline $\begin{array}{l}\text { Arranged employment } \\
\text { or designated occupation }\end{array}$ & 10 & 10 & 10 & 10 & 10 & 10 & 10 \\
\hline Language & 10 & 10 & 10 & 15 & 15 & 15 & 24 \\
\hline $\begin{array}{l}\text { Personal suitability/ } \\
\text { Adaptability }\end{array}$ & 15 & 15 & 10 & 10 & 10 & 10 & 10 \\
\hline $\begin{array}{l}\text { Levels adjustment factor } \\
\text { Or demographic factor }\end{array}$ & --- & --- & --- & 5 & 8 & 10 & -- \\
\hline Relatives & 5 & 5 & 5 & --- & -- & -- & 5 \\
\hline Kinship bonus & --- & --- & --- & $10 / 15$ & 5 & 5 & 5 \\
\hline Destination & 5 & 5 & 5 & -- & -- & -- & -- \\
\hline Total & 100 & 100 & 100 & $95-105 / 110$ & $105-110$ & $107-112$ & 100 \\
\hline Pass Mark & 50 & 50 & 70 & 70 & 70 & 67 \\
\hline
\end{tabular}

Source: Green and Green (1999), p. 433, plus updated information from CIC, 2007. Table 1 highlights a discretionary allocation that was used to control the amount of applicants entering Canada. The relatives factor was eliminated in 1986 as a selection factor for independent and skilled worker applicants. Prior to the 1986 change, assisted relative applicants (part of the family class) were not assessed on language, arranged employment, relatives and destination. The total and pass mark varied over time for the assisted relatives. The pass mark shown above applied to the independent and skilled worker applicants. 


\section{Table 2}

\section{Historical Canadian Immigration Policy Events from 1967 to the Present}

\begin{tabular}{|c|c|}
\hline 967 & $\begin{array}{l}\text { The point system was introduced through Order in Council. The point system } \\
\text { provided an objective scale based on education, age and language against which } \\
\text { applicants could be assessed. It was the key step to limiting the "discretionary } \\
\text { powers" of immigration officers and to providing them with a strict set of guidelines. } \\
\text { The point system's goal was to control unskilled flow. }\end{array}$ \\
\hline 1978 & $\begin{array}{l}\text { A new immigration Act defined three key goals of immigration policy. First, to speed } \\
\text { the process of family reunification of Canadian residents with close family members } \\
\text { from abroad. Second, to fulfill Canada's legal obligation with respect to refugees and } \\
\text { to pursue its humanitarian traditions. Third, to foster the development of a strong and } \\
\text { solid economy across all regions of Canada. A key feature was that it did not give the } \\
\text { Canadian Citizenship department the power to set limits on the amount of immigrants } \\
\text { in various components of the inflow. This Act was introduced as a result of failing to } \\
\text { control both the level and the composition of skilled inflow with points assessed for } \\
\text { "personal characteristics". These new admission rules failed because immigrants } \\
\text { could build up sufficient points on specific factors required for admission even } \\
\text { though their specific skills may have been in excess supply. }\end{array}$ \\
\hline 982 & $\begin{array}{l}\text { pplicants } \\
\text { government } \\
\text { ented in the } \\
\text { still held } \\
\text { fficulty in }\end{array}$ \\
\hline 8 & $\begin{array}{l}\text { Inual report to Parliament on future immigration reve } \\
\text { da had fallen below replacement levels. To make mat } \\
\text { begin to age and decline after the turn of the century } \\
\text { ained at its current low levels. As such, the governme } \\
\text { ation by removing the prerequisite of arranged emplo } \\
\text { ants. It also added the investor class, within which a } \\
\text { esting specific amounts in Canadian enterprises. The } \\
\text { become more than a small part of the inflow. This in }\end{array}$ \\
\hline 92 & $\begin{array}{l}\text { onservative government introduced a new immigration Act which gave the } \\
\text { ian Immigration Citizenship Department new regulatory powers, including the } \\
\text { to set limits on components of the inflow and turn away applicants once } \\
\text { c numbers had been achieved for a particular category. For example, the } \\
\text { iment proposed to use this Act to reduce the proportion of the inflow who were } \\
\text { family class "from } 52 \% \text { in } 1992 \text { to } 43 \% \text { by } 1995 \text { " (Green \& Green, 2004, } \\
\text { The government had given itself the power to set limits on various classes } \\
\text { ight have used their powers to limit the family and refugee classes in favour of } \\
\text { onomic classes, but they did not. This Act was the result of a desire to move } \\
\text { ls using immigration as an economic policy. During this time, a designated } \\
\text { ations list was formed which contained occupations in short supply in specific } \\
\text { ces. Immigrants who matched this list were given added points and processed }\end{array}$ \\
\hline
\end{tabular}




\begin{tabular}{|c|c|}
\hline \begin{tabular}{|l|}
1993 \\
\end{tabular} & $\begin{array}{l}\text { The government had made a commitment to stable inflows of "about } 1 \% \text { of the } \\
\text { current population and increased the size of the inflow to nearly } 250,000 \text { in } 1993 \text { in } \\
\text { spite of a persistently poor labour market" (Green \& Green, 2004, p. 125). This was } \\
\text { the first time that a Canadian government had responded to high unemployment rates } \\
\text { by increasing the size of the inflow. It is clear that the Canadian government saw } \\
\text { immigration as the ultimate generator of wealth. }\end{array}$ \\
\hline 1995 & $\begin{array}{l}\text { A radical new version of the point system was introduced. Under the new system, no } \\
\text { points would be assessed for demand in narrowly defined occupations and no points } \\
\text { would be awarded based on the skill levels of such occupations. Instead, a list of } \\
\text { skilled occupations was created and divided into four categories: professionals, } \\
\text { skilled administrators, technical occupations and trades. Applicants in all categories } \\
\text { would be assessed under the same criteria but would have to pass different critical } \\
\text { levels to gain entrance. Other changes in the point system included a significant } \\
\text { emphasis on education, proficiency in English/French, work experience and personal } \\
\text { suitability. Personal suitability, which was assessed by a visa officer, had also been } \\
\text { changed to emphasize flexibility in adjusting to labour market changes by adding } \\
\text { such variables as job search skills and a positive attitude toward personal growth, } \\
\text { development and learning. The Liberal government introduced a new policy } \\
\text { framework in a document called "Into the } 21^{\text {st }} \text { Century: A Strategy for Immigration } \\
\text { and Citizenship". A key element of the new framework was that immigration levels } \\
\text { were to be maintained at } 1 \% \text { of the population level, though target levels were set to } \\
\text { ranges instead of specific numbers. The document suggested that family class } \\
\text { applicants other than spouses and dependent children should be placed in a separate } \\
\text { class with numerical limits. The logic for the above policy changes was to ensure that } \\
\text { newcomers integrated, adapted and contributed to the Canadian economy as soon as } \\
\text { possible by participating in the labour market, "without adding to the burden on social } \\
\text { programs" (Green \& Green, 2004, p. 128). }\end{array}$ \\
\hline 2003 & $\begin{array}{l}\text { The Canadian government introduced "The Provincial Nominee Program". This } \\
\text { program was designed to improve the distribution of immigrants across the various } \\
\text { regions and communities of Canada. The provincial and federal government would } \\
\text { work together through various agreements that highlighted immigration as a key area } \\
\text { for bilateral collaboration and formalized how the two levels of government would } \\
\text { interact. The Immigration Refugee Protection Act was utilized to set the objectives } \\
\text { between the governments and increased the effectiveness of the program. }\end{array}$ \\
\hline
\end{tabular}

Source: Updated information on CIC, (2007); (2006), p. 10-11. In addition, Green \& Green, (2004), p. 117-128.

Table 2 displays the logic behind Canadian Immigration Policy. Shifts of economic, social and political goals have been ongoing. The Canadian government has a high level of commitment to maximize profit from the financial input of immigrants. 
Table 3

Canadian Immigration Levels Plan 2007 and Admission Categories

\begin{tabular}{|l|r|r|}
\hline \multirow{2}{*}{ Admissions Category } & \multicolumn{2}{|c|}{ Ranges } \\
\cline { 2 - 3 } & \multicolumn{1}{|c|}{ Lower } & \multicolumn{1}{|c|}{ Upper } \\
\hline Economic Class & & \\
\hline Skilled Workers & 90,000 & 100,500 \\
\hline Quebec Selected Skilled Workers & 26,000 & 27,500 \\
\hline Federal / Quebec Business & 9,000 & 11,000 \\
\hline Live-in Caregiver & 3,000 & 5,000 \\
\hline Provincial Nominees Program & 13,000 & 14,000 \\
\hline Total & $\mathbf{1 4 1 , 0 0 0}$ & $\mathbf{1 5 8 , 0 0 0}$ \\
\hline & & \\
\hline Family Class & & \\
\hline Spouses, Partners and Children & 49,000 & 50,000 \\
\hline Parents and Grandparents & 18,000 & 19,000 \\
\hline Total & $\mathbf{6 7 , 0 0 0}$ & $\mathbf{6 9 , 0 0 0}$ \\
\hline & & \\
\hline Refugee Class & & \\
\hline Government-Assisted Refugees & 7,300 & 7,500 \\
\hline Privately Sponsored Refugees & 3,000 & 4,500 \\
\hline Protected Persons in Canada & 10,600 & 12,000 \\
\hline Dependent Abroad & 5,000 & 6,800 \\
\hline Total & 25,900 & $\mathbf{3 0 , 8 0 0}$ \\
\hline & & \\
\hline Others & & \\
\hline Humanitarian \& Compassionate Grounds / Public Policy & 6,000 & 7,000 \\
\hline Permit Holders & 100 & 200 \\
\hline Total & $\mathbf{6 , 1 0 0}$ & $\mathbf{7 , 2 0 0}$ \\
\hline & & \\
\hline Total Sum & 240,000 & 265,000 \\
\hline
\end{tabular}

Source: CIC (2007), p. 9. Citizenship and Immigration Canada has a commitment to admit new permanent residents within a target range of between 240,000 and 265,000 admissions. The target for the Economic Class has been increased by 15,000 compared to the 2006 immigration plan. For the Family Class, CIC has also raised targets of the Spouses, Partners and Children category by 5,000 and the Parents and Grandparents category by 1,000 . 


\section{References}

Alboim, N., Finnie, R., \& Meng, R. (2005) The Discounting of Immigrants' Skills in Canada. IRPP, 11, no. 21-26.

Alboim, N., \& McIsaac, E. (2007) Making the Connections: Ottawa's Role in Immigrant Employment. IRPP, 13, no. 3 2-23.

Allen, J. (2003) The Time Pattern of Internal Migration: Human Capital Meets Job Matching. The Review of Regional Studies, 33, no. 3 284-295.

Antecol, H., Cobb-Clark, D.A., \& Trejo, S.J. (2003) Immigration Policy and the Skills of Immigrants to Australia, Canada, and the United States. The Journal of Human Resources, XXXVIII 193-218.

Argento, N. (2005, October 14). Canada Failing to Eliminate Employment Barriers for Immigrants. CanWest News, 1-2.

Bauder, H. (2003) "Brain Abuse", or the Devaluation of Immigrant Labour in Canada. Antipode, 38, no. 4 699-717.

Beach, C. M. "Employment-Based Permanent Immigration: Examining the Value of a Skills Based Point System". Paper presented before the U.S. Senate Committee on Health, Education, Labor, and Pensions on September 14, 2006. Available through Ryerson University database (08/09 2007)

Borjas, G.J. (1994) The Economics of Immigration. Journal of Economics of Literature, 32, no. 4 1667-1717.

Borjas, G.J. (1993): “Immigration Policy, National Origin, and Immigrant Skills: A Comparison of Canada and the United States," in D. Card and R.B. Freeman (eds.): Small Differences that Matter. Chicago: University of Chicago Press, 2143. 
Borjas, G.J., \& Hilton, L. (1996) Immigration and the Welfare State: Immigrant Participation in Means-Tested Entitlement Programs. The Quarterly Journal of Economics, 111, no. 2 575-604.

Borjas, G.J. (1996) The New Economics of Immigration: Affluent Americans gain; poor Americans lose. The Atlantic Monthly, 278, no. 572 (7).

Borjas, G.J. (1991) Immigration Policy, National Origin, and Immigrant Skills: A Comparison of Canada and The United States. National Bureau of Economic Research, NBER Working Paper Series 3691 1-28.

Citizenship and Immigration Canada. "Annual Report to Parliament on Immigration 2006". Retrieved July 4, 2007 from www.cic.gov.on.ca

Citizenship and Immigration Canada. "Government Response to the Report of the Standing Committee on Citizenship and Immigration”. Retrieved August 8, 2007 http: //www.cic.gc.ca/English/resources/publications/response/response-pnp.asp Citizenship and Immigration Canada. "Skilled Workers and Professionals: Who can Apply-Six Selection Factors and Pass Mark". Retrieved on August 9, 2007 from http://www.cic.gc.ca/english/immigrate/skilled/apply-factors

Citizenship and Immigration Canada. "The Canada-Quebec Accord". Retrieved on August 9, 2007 from

http://cic.gc.ca/english/resources/publications/you-asked/section09

Citizenship and Immigration Canada. "Federal-Provincial Agreements". Retrieved on August 9, 2007 from http://www.cic.gc.ca/english/resources/publications/youasked/section08.asp

Citizenship and Immigration Canada. "What Are the Categories of Permanent Residents?" Retrieved on August 9, 2007 from www.cic.gov.on.ca 
Citizenship and Immigration Canada. "Economic Class". Retrieved on August 10, 2007 from http://www.cic.gc.ca/english/resources/publications/you-asked/section12

Citizenship and Immigration Canada. "Criminal Justice and the Immigration and Refugee Protection Act". Retrieved on August 10, 2007 from http://www.cic.gc.ca/ENGLISH/resources/publications/justice

Citizenship and Immigration Canada. "Immigration and Refugee Protection Act". Retrieved on August 10, 2007 from http://laws.justice.gc.ca/en/l-2.5/index.html Coulson, R. G., \& DeVoretz, D. J. (1993) Human Capital Content of Canadian Immigrants: 1967- 1987. Canadian Public Policy, 19, no. 4 357-366.

CBC (2006). Interview with the Ministry of Canadian Immigration Citizenship with Minister Monte Solberg (it was accessed by television news).

The Conference Board of Canada (2001). Brain Gain: The Economic Benefits of Recognizing Learning and Learning Credentials in Canada, P. 1-4. (Unknown Publisher)

Dickens, W. T., \& Lang, K. (1992) Labour Market Segmentation Theory: Reconsidering the Evidence. National Bureau of Economic Research, Working Paper No. 4087, p. 1-80.

Dolin, B., \& Young, M. (2004). Background Paper: Canada's Immigration Program, Parliamentary Information and Research Services, p. 1-36 (Appendix 1-6). Economic Council of Canada (2006) A Lot to Learn: Education and Training in Canada, $1-5$.

Green, A. G., \& Green, D.A. (2004) The Goals of Canada's Immigration Policy: A Historical Perspective. Canadian Journal of Urban Research, 13, no. 1 102-139. Green, A.G., \& Green, D.A. (1999) The Economic Goals of Canada's Immigration 
Policy: Past and Present. Canadian Public Policy, 25, no. 4 425-451.

Green, A. G., \& Green, D.A. (1995) Canadian Immigration Policy: The Effectiveness of the Point-System and Other Instruments. The Canadian Journal of Economics, 28 , no. 4b 1006-1041.

Green, A. G., \& Green, D.A. (1992) Canadian Immigration Policy: The Effectiveness of Key Regulatory Instruments. Canadian Employment Research Forum Meetings, 1-64.

Hiebert, D. (2006) Winning, Losing, And Still Playing The Game: The Political Economy of Immigration in Canada. Journal of Economic \& Social Geography, 97, no. $138-48$.

Hiebert, D. (1997) The Colour of Work: Labour Market Segmentation in Montreal, Toronto and Vancouver 1991. Research on Immigration and Integration in the Metropolis, Working Paper Series 97, no. 02, 1-43.

Jimenez, M. (2006, October 27). Ottawa Rules out Amnesty for 200, 000 Illegal Workers. The Underground Economy: Construction Industry Hit Hard by Decision. The Globe and Mail, 1-3.

Kelley, N. \& Trebilcock, M. The Making of the Mosaic: A History of Canadian Immigration Policy. Toronto: University of Toronto, 1998.

McConnell, P. (2006) No Quick Fix for Lack of Skilled Labour. Daily Commercial News and Constructional Record, 7954 1-3.

Miller, P.W. (1999) Immigration Policy and Immigrant Quality: The Australian Points System. The American Economic Review, 89, no. 2 192-197.

Reitz, J.G. (2005) Tapping Immigrants' Skills: New Directions for Canadian Immigration Policy in the Knowledge Economy. IRPP, 11, no. 1 1-18. 
Reitz, J. G. (2001) Immigrant Skill Utilization in the Canadian Labour market: Implications of Human Capital Research. Journal of International Migration and Integration, 2, no. 3, 347-378.

Schaafsma, J., \& Sweetman, A. (2001) Immigrant Earnings: Age at Immigration Matters. Canadian Journal of Economics, 34, no. 4 1066-1099.

Simpson, J. (2007, February 7). Why Our Immigrant Assumptions are Off. The Globe and Mail, 1-2.

Statistics Canada (2007) The Daily: Study: Low Income Rates Among Immigrants Entering Canada, P. 1-4.

Sweetman, A. (2006). Need We Pursue Immigration Objectives One at a Time? Canadian Issues, P. 68-71.

Tastsoglou, E., \& Preston, V. (2006) Gender, Immigration and Labour Market Integration: Where We Are and What We Still Need to Know. CERIS No. 25, p.1-12. Teelucksingh, Ch. \& \& Galabuzi, G-E. (2005). Working Precariously: The Impact of Race and Immigrants Status on Employment Opportunities and Outcomes in Canada. Canadian Race Relations Foundation, 1-38.

Wanner, R.A. (2003) Entry Class and the Earnings Attainment of Immigrants to Canada, 1980-1995. Canadian Public Policy, 29, no. 1 53-71.

Williams, P. (2006) CCA to PM: Address Shortages. Daily Commercial News and Construction Record, 79139 1-2.

Yale-Loehr, S., \& Hoashi-Erhardt, Ch. (2001) A Comparative Look at Immigration and Human Capital Assessment. Georgetown Immigration Law Journal, 1-34. 


$$
20.521
$$

